\title{
What Enron Means for the Management and Control of the Modern Business Corporation: Some Initial Reflections
}

\author{
By Jeffrey N. Gordon†
}

On October 16,2001, Enron Corporation, a Houston-based energy trading and distribution company famous for its advocacy of energy deregulation, announced a $\$ 1.01$ billion nonrecurring charge related to "losses associated with certain investments ... and early termination during the third quarter of certain structured finance arrangements with a previously disclosed entity." Chairman and CEO Ken Lay reassured investors about the strength of the company's core businesses, said he was "very confident in [Enron's] strong earnings outlook" and "reaffirmed" that the company was "on track to continue strong earnings growth." Nevertheless, the write-offs produced a third-quarter loss of more than $\$ 600$ million and surprised Wall Street. Moreover, The Wall Street Journal reported that $\$ 35$ million of the losses derived from business dealings with partnerships managed by the company's CFO, Andrew S. Fastow. ${ }^{2}$

The bad news, the reported conflict of interest, an ensuing SEC investigation, and the fall in Enron's stock price from the mid- $\$ 30$ s to the low $\$ 20$ s, triggered a crisis of confidence in the company. Enron's energy trading business, its crown jewel, depended crucially on solid finances, since parties dealing with Enron were loath to assume significant counterparty credit risk: a serious chance that Enron could not perform on a contract to buy or sell energy meant that parties no longer would trade with the firm. In desperation, Enron turned to a merger with its crosstown rival, Dynergy, to save the day. Then, on November 8, Enron released a bombshell. The quarterly earnings statement restated (that is,

$\dagger$ Alfred W. Bressler Professor of Law, Columbia Law School. I appreciate discussion and comments from Jack Coffee, Ron Gilson, Victor Fleischer, Vic Khanna, Ed Iacobucci, Jon Macey, David Schizer, some Columbia alums who wish to remain anonymous, and participants at the University of Chicago Law Review Symposium. This Article bears a date of February 15, 2002.

1 Enron Corporation, press release, Enron Reports Recurring Third Quarter Earnings of $\$ 0.43$ per Diluted Share; Reports Non-Recurring Charges of \$1.01 Billion After-Tax; Reaffirms Recurring Earnings Estimates of $\$ 1.80$ for 2001 and $\$ 2.15$ for 2002 and Expands Financial Reporting (Oct 16, 2001) available online at <http://www.enron.com/corp/pressroom/releases/2001/ene/ 68-3QearningsLtr.html $>$ (visited Feb 19,2002). For a contemporary history of Enron's collapse, see Kurt Eichenwald with Diana B. Henriques, Enron's Many Strands: The Company Unravels; Enron Buffed Image to a Shine Even as It Rotted from Within, NY Times A1 (Feb 10, 2002).

2 John R. Emshwiller and Rebecca Smith, Enron Jolt: Investments, Assets Generate Big Loss, Wall St J C1 (Oct 17, 2001). 
reduced) previously reported earnings back to 1997 by $\$ 586$ million, a 20-percent reduction in profits over the period, "mostly due to improperly accounting for its dealings with partnerships run by some company officers." The quarterly statement revealed more about Enron's troubled financial relationship with officer-managed partnerships.

The third-quarter report was devastating. The ramifications led Dynergy to call off the merger. On December 2, barely six weeks after the crisis first broke, Enron filed for bankruptcy. The turnabout was remarkable. By some turnover measures, Enron had been the seventhlargest company in the United States. Barely a year before, its stock had crested at $\$ 90$ per share, yielding a market capitalization of approximately $\$ 80$ billion. The company was invariably mentioned in "most admired" lists of US companies; its CEO was lionized in Houston and a nicknamed confidant of the President of the United States.

Enron's collapse triggered investigations by a "special committee" of the Enron board, the SEC, the Justice Department, nearly a dozen congressional committees, and various shareholder plaintiffs' attorneys. The Enron board's special committee investigation suggested that a substantial fraction of the company's reported profits over a four-year period had been the result of accounting manipulations. Early targets included Enron's senior officers, the accountants at Arthur Andersen, the Enron board and its various special oversight committees, and the law firm Vinson \& Elkins, which helped put together the controversial transactions. Not only had Enron apparently filed false and misleading disclosure documents, but also insiders allegedly sold stock and exercised options while publicly restating their faith in the company. By contrast, rank-and-file employees were unable to sell their Enron stock locked into $401(\mathrm{k})$ retirement plans. This particular element-privileged insiders walking away with hundreds of millions of dollars in stock-related profits while ordinary employees were losing a substantial chunk of life savings-added to the political saliency of the events.

The Enron case plays on many different dimensions, but its prominence is not merely part of popular culture's obsession with scandal du jour. Rather, the Enron situation challenges some of the core beliefs and practices that have underpinned the academic analysis of corporate law and governance, including mergers and acquisitions, since the 1980s. These amount to an interlocking set of institutions that constitute "shareholder capitalism," American-style, 2001, that we have been aggressively promoting throughout the world. We have come to rely on a

3 John R.Emshwiller, et al, Enron Reduces Profit for 4 Years by 20\%, Citing Dealings with officers' Partnerships, Wall St J A3 (Nov 9, 2001).

4 See Report of Investigation by the Special Investigation Committee of the Board of Directors of Enron Corporation 4-5, 14-15 (Feb 1,2002), available online at <http://newsfindlaw.com/hdocs/ docs/enron/sicreport/indexhtml> (visited Feb 19, 2002). 
particular set of assumptions about the connection between stock market prices and underlying economic realities; the reliability of independent auditors, financial standards, and copious disclosure in protecting the integrity of financial reporting; the efficacy of corporate governance in monitoring managerial performance; the utility of stock options in aligning managerial and shareholder interests, and the value of employee ownership as both an incentive device as well as a retirement planning tool.

In particular, I want to assert that Enron raises at least the following problems for the received model of corporate governance:

First, it provides another set of reasons to question the strength of the efficient market hypothesis, because Enron's stock price reached dizzying heights despite transparently irrational reliance on its auditors' compromised certification.

Second, it undermines the corporate governance mechanism, the monitoring board, that has been offered as a substitute for unfettered shareholder access to the market for corporate control. In particular, the board's capacity to protect the integrity of financial disclosure has not kept pace with the increasing reliance on stock price performance in measuring and rewarding managerial performance.

Third, it suggests the existence of tradeoffs in the use of stock options in executive compensation because of the potential pathologies of the risk-preferring management team.

Fourth, it shows the poor fit between stock-based employee compensation and retirement planning. More generally, it raises questions about the shift in retirement planning towards defined contribution plans, which make employees risk-bearers and financial planners, and away from defined benefit plans, which impose some of the risk and fiduciary planning obligations on firms. ${ }^{5}$

\section{THE EFFICIENT MARKET HYPOTHESIS}

Although the efficient market hypothesis is a useful null hypothesis about the workings of a well-developed capital market, sophisticated application in policy settings requires awareness of its limits as well as its power. The 1987 stock market crash, which in retrospect still seems like a random quantum fluctuation, and the recent dot.com exuberance, which looks like a classic bubble, both give ample evidence of those limitations. Even if it is the case that the prevailing stock price is the best available estimate of expected future cash flows, "best" may not be very good in some cases. But Enron seems to demonstrate those limits in a new way. If the dot.com boom, for example, was a sectoral gold rush, Enron's price

5 For a wide-ranging account of the Enron collapse, see William W. Bratton, Enron and the Dark Side of Shareholder Value, 76 Tulane L Rev (forthcoming 2002). 
escalation (hitting a multiple of sixty on trailing earnings) showed how markets can ignore the handwriting on the wall for a single firm. It seemed barely possible that the Internet was about to become the prime medium for transactions in the United States and that the firms that staked their claims first would achieve increasing (and enormous) returns to scale. The failure of markets to assess adequately the earnings prospects at Enron is a more granular failure and thus more troubling. How can the market price so widely diverge from intrinsic value despite the firm-specific scrutiny that market institutions, including a battalion of securities analysts, bring to bear on such a widely held stock? Even if Enron lacked candor - indeed, actively misled - about its true financial condition, wasn't enough known to sophisticated market participants about the company's murky finances so that efficient markets never should have placed such a high value on Enron's stock?

The argument has a few steps. First, it was known and widely discussed in the analytic community that Enron's financial structure was highly complex and that the bodies were buried in off-balance sheet entities that were described cryptically in Enron's disclosure documents. No one on the outside really understood Enron's financial condition, but they also knew they did not know. As one analyst put it, Enron was a "faith" stock. Yet such willful obscurity ordinarily leads to skepticism rather than belief. Enron could have disclosed more but did not. It reveled in information asymmetry. What were we to infer from this: that it had a secret, nonpatentable elixir for moneymaking (that investment banks would not have already shopped to every other large firm)? Or rather that full disclosure would have been embarrassing? George Akerlof just won a Nobel Prize for providing the answer to that question. In other words, in an efficient market, Enron should have been a "lemons" stock instead of a "faith" stock.

Not so simple, you might say: Enron's accountants at Arthur Andersen certified that the financial statements "fairly presented" the overall financial picture of the company, and the reputational capital of a Big Five accounting firm credibly bonds Andersen's certification. Andersen's failure was a surprise, you might say. But, in fact, it seems to have been a foreseeable failure. That Andersen had a lot to lose from a bad audit is insufficient. No one who observed the firm-threatening bridge loans made in leveraged transactions in the 1980s by investment bankers eager for a success fee can believe that there is necessarily a link between what is rational for the firm and what actions may be taken by the firm's selfinterested agents. Much depends on the way the firm manages the inter-

6 George Akerlof, The Market for Lemons: Quality Uncertainty and the Market Mechanism, $84 \mathrm{Q} J$ Econ 488,489-92 (1970) (using the car market as an example to model the economic costs of dishonesty in the marketplace). 
nal moral hazard problems. On the basis of what we knew before the Enron collapse, the credibility of Andersen's certification had been severely compromised, first because it had permitted its independence as a firm to be fatally undermined, and second, because the internal governance of Andersen was insufficient to control potentially aberrant behavior by its partners.

Much has already been said about the problems raised by letting accounting firms cross-sell various consulting services to their audit clients. As one of my colleagues pithily put it, "The batter ought to worry about the umpire who is selling life insurance to the pitcher." But the issue bears close examination for what it says about the credibility of Andersen's certification.

The most important guarantor of an accountant's independence is that its firing is highly salient. This is a material event: it must be disclosed on a Schedule 8-K and even if the accountant breathes not a word about the precipitating facts (and the accountant may shout from the rooftop), it will trigger scrutiny and inquiry. Firing the accounting firm is thus a "high visibility sanction" that may well cause more harm to the sanctioning company (and its officers and directors) than to the accountant, and therefore it cannot credibly be threatened to bring into line an accountant who disagrees with management about an important accounting matter. Indeed, too vigorous an effort to force a particular accounting treatment may well trigger an accountant's resignation, also a material event.

This picture changes dramatically when the accounting firm begins to cross-sell consulting services. It is not that the accountant now has more at stake in the relationship and thus would lose more if fired by the company. Nor is it simply that the accountant may now have a particular reason to please, or at least not alienate, the client who may buy additional services, and may even hope that cooperation on difficult accounting questions will be appreciated as part of a total client relationship. Rather, it is that the client now has available a repertoire of "lowvisibility sanctions" to discipline the accountant's behavior. If the accountant is resistant, a contract may be withheld or not renewed (or if the accountant is cooperative, the reverse). But unlike the firing, these disciplinary measures will not be disclosed. (Even if the total amount of the accountant's consulting services is disclosed, the investor will not have a full picture of the accountant-issuer relationship, because the dis-

7 See generally John C.Coffee,Jr., The Acquiescent Gatekeeper: Reputational Intermediaries, Auditor Independence and the Governance of Accounting at 16-17, Columbia Law School Center for Law and Economics Studies Working Paper No 191 (May 2001), available online at $<$ http://papers.ssrn.com/id=270944> (visited Feb 19,2002) (suggesting that auditors also selling nonaudit services to corporate clients can no longer be gatekeepers whose revenues from clients are too small for an auditor to risk its reputation in agreeing to an accounting irregularity). 
closure will not reveal the set of potential contracts.) Thus the issuer now has credible threats against an accountant who disagrees with management on an important issue. Moreover, the issuer now knows the accountant's type: No accounting firm that prizes its independence above all else would put itself in a position where that independence is so readily undermined. To push the argument further: this may be why there are two polar equilibria in the bundling of auditing and consulting services. Accountants cannot afford to compete on their relative independence. The willingness to expose oneself to low-visibility sanctions - the sacrifice of inherent independence-offers such a competitive advantage in attracting audit clients that there will be a race to the bottom.

There is a related cultural factor associated with consulting that also tends to undermine the credibility of the accountant's certification. The press often has referred to the bundling of auditing and glamorous information technology consulting. But the more common, and more insidious, bundle may be auditing plus tax planning, because of the carryover mindset from "tax planning" into "accounting planning." Tax planners provide value by structuring a company's transactions so as to minimize tax, applying a formalist's approach to the constraints of the tax law against a background interpretive norm of "reasonable basis." If a close, ingenious reading of the Code and the regulations permits a reshaping of economic reality to minimize taxes, then excelsior. Whatever the ultimate social desirability of such gamesmanship, at least it serves the narrow shareholder interest of maximizing after-tax income, that is, increasing the cash in the corporate till. But this tax planning approach all too readily carries over to "accounting planning," in which the accountant aggressively construes accounting rules to maximize reported income irrespective of less illuminating disclosure to the ultimate client, the shareholders. Accounting rules, like tax rules, become the subject of professional manipulation, despite a potentially distorted portrayal of the underlying economic reality. The ingenious evasion wins a merit badge and perhaps additional compensation. "Thus "independent" accountants become part of the management "team." Moreover, the balance sheet is disaggregated, as each successive transaction is evaluated on a stand-alone basis against the accounting rules, myopically applied. So in addition to the low-visibility sanctions, consulting can create a culture that undermines the capacity of the accountant to make the arm's length judgment about public financials that must "fairly present" the underlying economic realities taken as a whole.

Yet all of this is known to sophisticated investors. The sharply diminished value of Andersen's certification for a company like Enron with

8 The Enron Special Committee report confirms Andersen's role in helping to structure Enron's off-balance-sheet entities despite the obvious disclosure deficit that was created. 
complicated accounting, abundant consulting opportunities, and obvious accounting planning should have been impounded in Enron's price from the get-go. Apparently, it was not.

There is a second compromising element of the value of Andersen's certification, the weakness of its internal governance mechanisms in controlling the behavior of the firm's partners - the internal agency problem.'The previous paragraphs addressed the independence of Andersen as a firm, but of course services were delivered by specific agents of the firm, its Houston partners. It now seems that the compensation of the Houston partners was significantly tied to their client billings both for auditing services and for consulting services. Enron might have been a relatively small client for Andersen, the firm, but it was the largest client for its Houston office, and, for the Enron relationship partners, perhaps their only significant client. The forces that would undermine the independence of the firm are much magnified in the case of the relationship partners. In a multi-office, multi-national firm like Andersen, it may be economically rational to treat each office as a profit center and to tie a significant portion of partner compensation to own-billings or officebillings. But the consequent threat to the partner's independence and the resulting risk to Andersen's reputation are foreseeable and seem virtually to compel an appropriate internal monitoring mechanism. The disparity between the value of the Houston partners' share of Andersen's reputation and the value to them of a continued (or more lucrative) Enron client relationship sets up an obvious moral hazard problem. This problem is compounded by the interaction with the first compromising factor. That is, the low-visibility sanctions associated with the bundling of audit and consulting services have particular compromising force at the relationship partner level because of the impact of lucrative consulting contracts on relationship partner compensation.

There are at least two obvious ways to monitor. First, an internal "inspector general" might provide disinterested internal review of important accounting judgments made by the Houston partners, an internal auditor's audit. Second, partners might rotate among offices (for the same reason that bank officers frequently rotate). Neither of these mechanisms, nor any other, seems to have been used by Andersen. Indeed, it seems that the Houston office could reject accounting judgments from Chicago headquarters with impunity. ${ }^{10}$

9 This section benefited particularly from conversations with Jon Macey.

10 For accounts of the cultural and monitoring failures at Andersen, see Ken Brown and Jonathan Weil, How Andersen's Embrace of Consulting Altered the Culture of the Auditing Firm, Wall St J C1 (Mar 12,2002); Ianthe Jeanne Dugan, Did You Hear the One About the Accountant? It's Not Very Funny, Wall St J A1 (Mar 14, 2002).

Andersen's internal monitoring failure is one of the genuine puzzles about Enron. After all,Andersen's business, its core competence, if you will, is anticipating internal agency problems, especially 
But this absence of internal controls was no secret. It was widely known, one presumes, to accounting sophisticates, and thus the consequent undermining of the credibility of Andersen's certification should have been impounded in Enron's price. Yet throughout the period that Enron was assembling its deceptive array of off-balance-sheet partnerships and special purpose entities, its stock soared.

How are we to interpret the gradual fall in Enron's stock price during 2001, in absolute and market-adjusted terms, despite steadily increasing reported earnings during the period? The stock price hovered around $\$ 80$ per share in January and February, drifting down to $\$ 60$ in March and April, falling to $\$ 50$ in the summer and to $\$ 40$ by early fall. Yet the company was reporting favorable operating results, including substantial increases in quarterly earnings per share, an 18 percent increase for the first quarter, a 32 percent increase for the second quarter.Perhaps there was information leakage from the partnership participants, who possessed nonpublic deal documents that could have revealed the potential fragility of Enron's accounting alchemy, or perhaps the pressure of skeptical short sellers was having an effect. This provides only limited vindication of the efficient market hypothesis because of the slow correction of the initial overpricing. Indeed, the pattern is consistent with an undersupply of arbitrage in the presence of "noise traders," one of the by-now classic explanations of the limitations on market efficiency."

In short, Enron disturbs the efficient market hypothesis. The only compelling reason not to assume the worst about Enron's deliberately obscure financial statements was because of Andersen's certification, yet the market "knew" that the certification had little value. ${ }^{12}$

in the financial realm, and figuring out how to minimize the consequent risks through internal monitoring systems. How is it that this shoemaker failed to make shoes for itself? One benign explanation is that Andersen, the firm, failed to realize its evolution from a partnership of accounting professionals, "certified public accountants" constrained by a strong sense of professional ethics, to a profitmaximizing business organization using high-powered incentive compensation schemes. The internal monitoring systems that might suffice in the case of the former are woefully inadequate in the case of the latter. In the course of pursuing consulting business and in devising compensation systems designed to maximize partner incomes, Andersen underwent a "norms shift" that required a matching change in the internal monitoring system. Perhaps the partners were unable to look at themselves hard enough in the mirror (or to hold a mirror to the firm).

This observation may have implications for the large law firm, another organization of professionals, "lawyers," which in general is moving towards incentive-based compensation. The internal monitoring system may have been appropriate for a small organization of "partners" who were compensated on a lock-step system and who may have highly valued a sense of professional identity, but will not be appropriate for a profit-maximizing large firm using high-powered incentive compensation schemes. Not only will the sense of "professional ethics" change, but such an environment will put greater pressure on such constraints. Law firms, like accounting firms, may find themselves at significant risk in the absence of strenuous internal monitoring.

11 For a summary, see Andrei Shleifer, Inefficient Markets: An Introduction to Behavioral Finance 28-52 (Oxford 2000).

12 The suggestion that Enron's $\$ 90$ stock price could be justified as the weighted average of investor expectations (for example, a 50 percent chance that Enron was worth $\$ 180$ a share, a 50 per- 


\section{BOARD-CENTERED CORPORATE GOVERNANCE}

The efficient market hypothesis has been one of the underpinnings of the argument for shareholder choice in the decision whether to accept a hostile takeover bid at a premium to the market price. (It is by no means a necessary step to that conclusion, however, since the possibility of a gap between prevailing market price and intrinsic value hardly resolves the question of whether management has markedly better information and superior evaluative skills so as to outweigh the agency problems.) Those who argued most strenuously against unfettered shareholder access to hostile bids, for management's right to "just say no," have offered the visible hand of robust corporate governance instead of the market in corporate control as a solution to the agency problems of large public corporations. That is, the appropriate remedy for the problem of the potentially self-interested or incompetent managerial team is said to be the monitoring board. The major features are independent directors, specialized committees (especially an audit committee) consisting exclusively of independent directors to perform crucial monitoring functions, and clear charter of board authority. Some have argued additionally for stock-based compensation for directors, better to align their interests with shareholders.

Enron is an embarrassment for this position. Its board was a splendid board on paper, fourteen members, only two insiders. Most of the outsiders had relevant business experience, a diverse sèt including accounting backgrounds, prior senior management and board positions, and senior regulatory posts. Most of the directors owned stock, some in significant amounts, and almost all had received stock options or phantom stock as part of the director compensation package. The Audit Committee had a state-of-the-art charter, attached to the 2001 Proxy Statement for all to admire, which made it the "overseer of the Company's reporting process and internal controls" and gave it "direct access to financial, legal, and other staff and consultants of the Company" and the power to retain other accountants, lawyers, or consultants as it thought advisable. But if the report of the Enron Special Investigation Committee is accurate, the board was ineffectual in the most fundamental way, the Audit Committee particularly somnolent if not supine. It turns out that the independence of virtually every board member, includ-

cent chance that it was worth nothing) is consistent with the usual lemons equilibrium. Purchasers who are unable to determine whether the good is high or low quality assume they are purposefully being kept in the dark; they offer the low-quality price, not an average-quality price. (More technically, the value of Enron was not a "normally distributed random variable." At the very least, the "low-quality" outcome should have been much more heavily weighted than the "high-quality" outcome.) Note also that the $\$ 90$ stock price reflected a price-earnings multiple of sixty. It is hard to imagine $\$ 90$ per Enron share as the expected value of a probability distribution that gave significant weight to a low-quality outcome. 
ing Audit Committee members, was undermined by side payments of one kind or another. ${ }^{13}$ Independence also was compromised by the bonds of long service and familiarity.

Obviously one bad board does not an argument undo, but it does reveal a certain weakness with the board as a governance mechanism. Much is made of the heuristic biases of investors that undercut the reliability of stock market prices, but Enron reveals that the heuristic failings of small groups may be even more pronounced. The gap between what the Enron board knew and could have/should have known is far greater than the valuation gap between intrinsic and market values that typically emerges from competitive markets (one-third, Fisher Black famously suggested). Things at Enron appeared to be going so well, and management told such a convincing story, that a tell-tale sign of trouble - the proposal to suspend the corporate ethics code to permit conflicted transactions by a senior executive, an extraordinary request-did not stir the antennae. Skepticism, suspicion, and healthy scrutiny were inconsistent with the board's culture. Yet this sort of cognitive dissonance, which is probably wide-spread at corporations that appear successful, is also probably very common even at corporations in some trouble. Boards always seem to think that hostile bids undervalue the firm.

The Enron board failure also may reveal a certain tension in the current modes of director compensation and selection. Recruitment of directors who are qualified to be board members of a large public company may require substantial compensation, especially for directors on time-consuming or high-profile committees such as the audit committee. Yet high levels of compensation may compromise director independence, since a director's sharp questioning of senior management may lead to subtle pressures against his/her renomination. Moreover, stock-based director compensation may enhance the board's vigor as a shareholder agent but also increase its ambivalence about uncovering embarrassing facts that will reduce the share price. Finally, directors' independence can be compromised by both "soft conflicts," such as significant charitable contributions to an institution where a director may have a strong affiliation, or more direct conflicts, such as consulting arrangements. Both of these sorts of conflicts open the door to low-visibility sanction, this time against director independence. The failure to renominate a director is high-visibility, and, much as the accountant firing, may stir inquiry, whereas the making or not of a charitable contribution, or entering into or not of a consulting arrangement, are much lower visibility and thus in practice may undercut independence even more.

13 See Joanne S. Lublin, Inside, Outside Enron, Audit Committee Is Scrutinized, Wall St J C1 (Feb 1, 2002). 
One possible way to mitigate some of these tensions is to change the nominating and compensation practices for what might be called "trustee" directors in large public corporations. Even where the nominating committees consist of nominally independent directors, the CEO often plays a significant backstage role. Perhaps the members of the audit committee, for example, should, in ordinary course, be "self-nominated," that is, the committee should have the power to designate the managerial nominees for directors who will be expected to serve on the audit committee (except that a proxy contestant should have the power to make an initial designation of its own audit committee nominees). This would provide a useful safeguard of independence. ${ }^{14}$ Compensation for audit committee members should be different, a flat fee (or time-charged) rather than incentive-based. Audit committee members are in a real sense the board's and thus the corporation's compliance officers. To protect both the reality and appearance of their willingness to ferret out bad facts, they should not receive compensation closely tied to the corporation's profits or stock price. Finally, charitable contributions or other side payments related to a director's service should simply be eliminated, if not for all directors, then certainly for audit committee members and perhaps other "trustee" directors.

A group of "trustee directors" subject to different nomination and compensation rules differs, to be sure, from the usual U.S. pattern of generalist, nonconstituency directors. For example, employee-designated directors are a decided rarity in U.S. public corporations, found most prominently in an employee-owned firm like United Air Lines. The board's most important decisions typically involve matters of overall business strategy or executive leadership in which "trustee"-type considerations may not loom large, and arguably a single-minded focus on shareholder value assures the best outcomes. But a trustee director class would not disrupt the functioning of the board. In all probability, they would have the same general attitudes toward shareholder value as other directors, since ultimately they are elected by and accountable to the shareholders generally, not a particular constituency. The members of this class would be strengthened to function on behalf of shareholders in circumstances where independence from management may be crucial.

The "trustee director" approach may seem more attractive when compared to other approaches in light of Enron-type board failure. One alternative is to raise legal liability for directors for breach of the duty of care, or more particularly, breach of the duty of managerial oversight.

14 For another mechanism to protect director independence, see Ronald J. Gilson and Reinier Kraakman, Investment Companies as Guardian Shareholders: The Place of the MSIC in the Corporate Governance Debate, 45 Stan L Rev 985,990-96 (1993) (proposing to institute publicly traded financial intermediaries that would make huge investments in small portfolios). 
This could be done in several different ways: expanding the circumstance in which liability might be attached, ${ }^{15}$ narrowing the scope of director liability exculpation statutes to increase exposure to significant monetary loss, or, to similar effect, curtailing the availability of corporate indemnification or directors and officers liability insurance. Another alternative is to create mechanisms that more potently "forfeit" the reputational "bond" that directors allegedly post as a guarantee of good performance. For example, in cases of significant board oversight failure, the SEC could bring a proceeding to bar the directors from serving on other public boards or institutional investors could work privately to establish such a practice. (A lesser sanction would be a disclosure requirement associated with director nomination of a party who had served on the board of a company sanctioned by the SEC for a serious disclosure violation.) Each of these alternatives depends upon accurate ex post determination of board failure followed by application of appropriate sanctions, monetary or reputational. It is a familiar move in the debate to observe that such measures may have the perverse effect of discouraging board service by the well-qualified, especially for corporations facing significant business challenges.

By contrast, the "trustee director" approach is structural: it aims to affect the overall performance of the board by buttressing the particularly important role that certain directors must perform without changing the applicable legal duties. It represents the next stage in the evolution of board governance of the large public corporation, in which firms and managers must anticipate the pressures (and temptations) of competitive capital markets.

An "audit committee" for public corporations is itself a relatively recent innovation, a product of the 1970s corporate governance movement. ${ }^{16}$ In light of the increasing reliance on stock prices as the measure of both managerial performance and compensation, the audit committee has become an increasingly important institutional complement for the control of the associated moral hazard problems. If relatively small changes in earnings, or the growth rate of earnings, have significant impact on the stock price, and if management receives a significant portion of its compensation through stock options, the temptations are obvious. Indeed, the increasingly widespread practice of "earnings management" was the basis for the SEC's very recent efforts to strengthen the role and accountability of audit committees. ${ }^{17}$ The Enron case reemphasizes the

15 See In Re Caremark International Inc Derivative Litigation, 698 A2d 959, 967-70 (Del Ch 1996) (describing circumstances in which liability is currently attached).

16 See Principles of Corporate Governance: Analysis and Recommendations \$3.05 Reporter's Notes (ALI 1994).

17 See generally Gregory S. Rowland, Note, Earnings Management, the SEC, and Corporate Governance: Director Liability Arising from the Audit Committee Report, 102 Colum L Rev 168 
importance of audit committee independence and vigilance and suggests possible structural weaknesses in its present conception. Audit committees would be strengthened if their members were "trustee directors."

\section{STOCK-BASED EXECUTIVE COMPENSATION AND EMPLOYEE COMPENSATION}

Stock-based compensation has emerged as a major tool in the employment contracts, express and implied, for both senior managers and employees. The overly high-powered incentives of executive stock option mega-grants may have contributed to Enron's downfall.

Stock options have become an increasingly important element in executive compensation. In part, this has developed from appreciation of the need to align managers' and shareholders' incentives to solve genuine problems of legitimately different perspectives. This has "finance" elements and "real" elements. On finance: managers and shareholders start with different attitudes toward firm-specific risk. Managers generally make large firm-specific human capital investments in their firms and thus are risk-averse; shareholders in public firms generally are reasonably well-diversified (or at least have the opportunity to be) and thus are generally risk-neutral. Managers therefore might well choose projects with lower expected returns but less variance than shareholders otherwise would prefer. Executive stock options can solve this mismatch by compensating executives for the additional risk of the shareholderpreferred projects.

Stock options also can give managers particular incentives to undertake difficult measures that may even reduce the riskiness of the firm but that may be personally stressful. For example, competition inevitably means that large firms should exit from some losing businesses, close plants, redeploy assets and make other moves that will disrupt the lives of employees and other stakeholders, but that also will increase the value of the firm. Stock options have become a dominant mode of performance-based pay for senior managers. Options are favored in part because of a peculiar mismatch between accounting and tax consequences: the grant of stock options is not booked as an "expense" that reduces accounting earnings, yet, when exercised, options produce a tax deduction for the firm equal to the difference between the market value of the stock and the exercise price of the option. Stock options also can serve a coordinating function among the senior management team, promoting

(2002). Former SEC Chairman Arthur Levitt focused on audit committees as a governance response to earnings management in 1998. This led to a report of the Blue Ribbon Committee on Improving the Effectiveness of Corporate Audit Committees in 1999 and subsequent standard setting by the stock exchanges and rulemaking by the SEC, effective in 2000. See The Blue Ribbon Committee, available online at <http://www.nyse.com/content/publications/NT00006286.html > (visited Mar 23, 2002). 
team efforts to increase the value of the "firm" and mitigating the tendency to aggrandize one's own particular "division" of the firm. These are examples of the "real" motives for stock options.

Stock options also have emerged as particularly important in contemporary mergers and acquisitions practice because of the power that courts and legislatures have given to target boards to refuse a hostile bid. As I have argued previously, stock options have become the currency with which stockholders have bought back the endowment that courts and legislatures have so generously conferred on management. ${ }^{18}$ This works through the senior executive employment contract. At the outset of the contract the senior executive is given a pile of stock options that will vest over perhaps a ten-year period, a golden handcuff, you might say. But there is a crucial "acceleration clause" that provides for immediate vesting of the options in the event of a change in control. An executive who fought fiercely in the 1980 s to preserve position, perquisites, and power is now quite willing to sell.

In each case, executive stock options are used to solve a problem of incentive compatibility. But frankly, no one really knows what is the optimal level of option grant: what level of stock option compensation will make an executive risk-neutral like the shareholders, or willing to bite the bullet on layoffs, or willing to accept a premium bid? Indeed, it is likely that each problem may have a different solution as to number, term, and exercise price. The optimal level also may vary depending upon the utility curve of the particular executive, which may be affected, for example, by outside wealth. So at best, the actual grant must trade off among a number of objectives. Nor is it realistic to think that the market in executive services functions very well in setting the level of option grants, particularly because the present accounting treatment of options makes them nominally costless to the corporation. But as option grants become increasingly larger, two pathologies may arise that seem to have been at work in Enron: first, the fraudster, and second, the riskpreferring executive. (The more commonly identified problem, shareholder dilution, is merely distributive, not a potential threat to the existence of the firm.)

Stock options have value, of course, only if at exercise they are "in the money," meaning the stock price is above the exercise price. If option grants are very large and exercisable in the relatively near term, then a positive swing in the stock price can make the senior executives immediately very rich. Even if the stock price falls back, the well-timed executive option exercise is a life-changing experience. More formally, the Black-Scholes option pricing model instructs us that the value of the ex-

18 See Jeffrey N. Gordon, Poison Pills and the European Case, 54 U Miami L Rev 839, 841 (2000). 
ecutive's stock option will be increasing both in the value of the underlying security and the variance (since stock options are issued "at the money"). So managers with a rich load of options have incentives to get the stock price high by any means necessary, fraud included. In particular, they have incentives to increase the riskiness of the firm, including projects that offer lower expected returns but higher variance. This will reduce the value of the firm for risk-neutral shareholders but has the potential to increase the value of managers' firm-related investments in cases where the gain in option holdings exceeds the loss to human capital. Managers become risk-preferring. Both pathologies, fraud and costly risk-taking, appear to have occurred in Enron. Enron became a hedge fund, taking leveraged bets in exotic markets that if successful would produce a huge, disproportionate bonanza for its executives. In particular, for a management team that had profited from previous option exercises, the downside seemed a problem only for the shareholders.

\section{EMPLOYEE STOCK OWNERSHIP AND RETIREMENT PLANNING}

The Enron case exposes the weirdness of brigading employee stock ownership, used principally for incentive purposes, with employee retirement planning. First, employer stock is a strange tool for delivering incentives to employees. For all but senior management, the action of any individual employee will have negligible impact on the stock price. Even a major contribution to enhancing the profitability of a division is likely to go unnoticed in the consolidated results of a large public company. More precisely tailored pay-for-performance measures, bonuses, commissions, promotions, and other rewards for delivering specific results are bound to be far more effective in providing incentives. ${ }^{19}$ Too stringent a focus on ownership of employer stock for its incentive effects may lead to employee disillusionment when strong individual efforts are not rewarded by a stock price increase. Rather, ownership of employer stock may serve other organizational goals. The stock price, which reflects the public market's evaluation of the company, is a salient benchmark of the company's success. Management can use this focal point to rally the troops, to explain the need for difficult economic decisions, to build a sense of a common enterprise and common culture. The stock is a common currency within the company. Unlike a grand title or corporate power, it is infinitely divisible. Every employee can have some; it is "commons" stock. Employer stock can also serve as a form of profitsharing that does not require a cash outlay by the company and which receives favorable accounting treatment.

19 For a related view,see Saul Levmore, Puzzling Stock Options and Compensation Norms, 149 U Pa L Rev 1901, 1905-08 (2001) (comparing the incentive effects of stock options and bonuses). 
The tie-in to retirement planning makes employer stock particularly odd as an incentive device. Employer stock is typically placed into a contributory pension plan, for example, a 401(k) plan or an Employee Stock Ownership Plan, which places strict limits on the employee's ability to sell the stock, and even after sale, locks up the proceeds until the employee's retirement. Thus the employee is required to take a very long view towards the benefits of employer stock appreciation. ${ }^{20}$ Consumption is postponed a long time. In theory, there should be substitution among various savings vehicles, so employer stock appreciation in a retirement account should reduce other savings, increasing the amount available for consumption, but the mental arithmetic seems not to work that way in practice. Note that this pattern also is very different from the incentives granted to senior managers-stock options and other stock-based compensation that begin to vest and become exercisable as quickly as one year after their grant. In other words, the wealthier senior managers whose declining marginal utility should make them more likely candidates for incentives that pay off in the long run receive short-fused stockbased incentive compensation. If that is the right payoff horizon for incentivizing senior management, then the retirement planning link to stock-based incentives for line employees postpones the payoff long past the point of incentive compatibility.

The limited value of employer stock as an incentive device in these circumstances is, of course, the much less serious half of the retirement plan problem. Enron employees were heavily invested in employer stock in their $401(\mathrm{k})$ plans. An estimated $\$ 1.3$ billion of the plan's $\$ 2.1$ billion in pension assets consisted of now-worthless Enron stock. ${ }^{21}$ To a significant extent, this was the result of the peculiar accounting and tax incentives that reduced Enron's cost of pension contributions if it used its own stock combined with the pension plan rules that limited employee sales of Enron-contributed stock until age fifty. Presumably, those tax incentives could be redirected to reward greater diversification. But employee choices to remain undiversified also accounted for a significant portion of these losses. The extent to which Enron's employees - probably much higher on the financial sophistication curve than most-chose to take on so much uncompensated firm-specific risk is stunning.

Enron shows why we might regret the diminishment of the defined benefit pension plan and the shifting of retirement planning risk onto

20 See generally Jeffrey N. Gordon, Employee Stock Ownership in Economic Transitions: The Case of United Airlines, in Klaus J. Hopt, et al, Comparative Corporate Governance: The State of the Art and Emerging Research 387, 433-34 (Oxford 1998).

21 Theo Francis and Ellen Schultz, Enron Faces Suits by 401 ( $k$ ) Plan Participants, Wall St J C1 (Nov 23,2001). Of course, these figures overstate the employees' true loss since the value of Enron stock was pumped up by the accounting manipulation. 
employees. . Defined benefit plans, which promise a fixed payout based on an employee's longevity with the firm and his/her final salary, are collateralized by funding requirements set by the Employee Retirement Security Act of 1974 (ERISA) and managed by fiduciaries who operate under a prudent investor standard that emphasizes the value of diversification. Defined contribution plans generally, and 401(k) plans specifically, are the fastest-growing part of the private retirement planning universe. $^{23}$ Employees contribute a before-tax portion of their salaries, and employers often match, especially with employer stock, but all of the risk associated with the individual's management of his/her retirement savings is borne individually. Ironically, the problem until recently was that individuals typically underweighted equities, preferring instead less risky bonds and other fixed-income investments. Such conservatism meant that they would not attain retirement income targets. The Enron experience of a poorly diversified 401(k) plan, too much in employer equity, is of course just the opposite. It seems likely that the failures of individual retirement portfolio management will cluster around these two poles.

Since pension plans are voluntary for the employer, reform needs to avoid imposition of significant new costs. But the devolution to individuals of both the responsibility for retirement-plan planning and the investment risk of their choices seems unwise.

\section{CONCLUSION}

The Enron matter will prove to be a very important event in the history of American shareholder capitalism. Many of the important institutions were subjected to a stress test at a particular firm and the outcome was poor. The real concern is that the gross overreaching at Enron is symptomatic of troubling if not egregious behavior elsewhere. Already, reform seems on the way, in the possible restructuring of accounting firms and the establishment of a new accounting self-regulator; in clearer standards under GAAP about the treatment of specialized financing vehicles; in new elements of mandatory disclosure; in efforts to redefine director independence. But Enron also reminds us that there is a problem that cannot be solved, but can only be contained, in the tension

22 For some discussion of the risks of defined-contribution, Enron-type plans for employees, see Jeffrey N. Gordon, Individual Responsibility for the Investment of Retirement Savings: A Cautionary View, 64 Brooklyn L Rev 1037,1038 (1998) (discussing the poor assessment by individuals of the risks that arise from the volatility of stocks versus bonds); Jeffrey N. Gordon, Employees, Pensions, and the New Economic Order, 97 Colum L Rev 1519,1541-45 (1997) (noting employer obligations to employees under defined-benefits plans, and the undermining of those plans in the current economic trade-liberation order).

23 See Council of Economic Advisors, Economic Report of the President 71 (2002), available online at <http://w3.access.gpo.gov/eop/> (visited Apr 18, 2002) (including a chart comparing the growth in numbers of defined-contribution plan participants with the growth in numbers of defined benefit plan participants). 
that cannot be solved, but can only be contained, in the tension between imperfectly fashioned incentives and self-restraint. 